\title{
The Evident Need for Banking Reform in the Legal Marijuana Industry
}

\author{
Jonathan James, PhD \\ Walden University, Minneapolis, Minnesota, United States \\ Contact: jonjames50@gmail.com \\ Steven Tippins, $\mathrm{PhD}$ \\ Walden University, Minneapolis, Minnesota, United States \\ Contact: steven.tippins@mail.waldenu.edu
}

\begin{abstract}
Marijuana reform legislation has created a lucrative industry for legal marijuana on the local and state level in some jurisdictions. Federal laws have forced legal marijuana dispensaries to be cash-only businesses with limited banking options. The lack of normal banking services has also affected firms' ability to manage profits earned from operations. Our hermeneutic phenomenological study was grounded by the conceptual framework of the motivations of humans and humans' need to feel safe. The participants in this study were owners and operators in the legal marijuana industry in Colorado. Data were collected through interviews, although the Coronavirus (COVID-19) pandemic of 2020 made data collection more challenging because of the added pressure on potential participants. The data analysis plan for this study consisted of transcribing and reviewing the data, coding themes and supporting themes, and synthesizing and reporting findings from the data collected. The study's findings included the participants' concerns about safety in their cash-only operations, their methods for conducting business, and the banking options available to them. Common themes that emerged from the interviews were cash, banking, safety, and the limitations of business size. Findings from my study contribute to fostering positive social change on the organization and industry level by providing accounts of how owners and operators navigate the banking dilemma in the legal marijuana industry.
\end{abstract}

Keywords: legal marijuana industry, banking, lived experiences

Date Submitted: March 24, 2021 | Date Published: August 13, 2021

Recommended Citation

James, J., \& Tippins, S. (2021). The evident need for banking reform in the legal marijuana industry. Journal of Social Change, 13(2), 80-91. https://doi.org/10.5590/JOSC.2021.13.2.07

\section{Introduction}

The possibility of national legalization of marijuana is no longer an abstract idea. More states are legalizing marijuana for adult use in every election cycle. Therefore, it is important to fully understand the challenges that face many of the participants in the legal marijuana industry as we know it currently. In this study, we focused on dispensaries in the state of Colorado, but there are lessons for the broader industry.

Legal marijuana business owners in Colorado are at the forefront of an emerging new industry in the United 
States. The potential national legalized marijuana industry could create annual revenues ranging up to $\$ 35$ billion (Eastman, 2016). There are, however, conflicting bodies of government that govern marijuana firms. Marijuana use is legal in Colorado and many other states, but it is illegal on the federal level, and the banking industry is primarily governed on the federal level. Thus, legalized marijuana businesses struggle to manage their day-to-day operations without banking services. The legitimacy of the industry is put into question by the nature of storing cash in vaults and warehouses with large numbers of security personnel needed (McKendry, 2016). In this study, we interviewed the primary operators in the industry to learn how they have dealt with and adapted to this situation; the findings can inform current and future owners on how to address lack of access to banking services.

\section{Background of the Study}

Marijuana reform legislation has created opportunities in some states for the ownership of a legal marijuana enterprise. However, these firms have had difficulty or been unable to secure bank accounts. Even if the firms do find a bank that will work with them, they are unable to use credit cards and must resort to using cashless ATMs to help process transactions. The cashless ATM-which simulates a debit card payment by letting consumers initiate a cash withdrawal and then direct those funds to the merchant-is meant to make it easier for legal dispensaries and other high-risk stores to accept card payments (Wynn, 2017).

Despite the potential of the marijuana industry, federal money-laundering laws apply to certain common financial transactions with legal marijuana businesses. For example, merely receiving a payment of more than $\$ 10,000$ from a known marijuana business may be a federal crime punishable by up to 10 years in prison (Kamin \& Moffat, 2016). Additionally, a vendor who supplies packaging material or agricultural equipment to a legal marijuana business, knowing that those goods will be used to help the business operate, may be committing a 20-year felony by accepting payment for those goods. An accountant who receives payment for maintaining the legal marijuana business's financial records could also be violating the law (Kamin \& Moffat, 2016).

\section{Problem Statement}

New revenue streams have been a motivation for state governments, such as Colorado, Oregon, and Nevada, to legalize marijuana. Investors and venture capitalists have realized that there is potential in the growing legal marijuana industry (Eastman, 2016). The general problem we addressed in this study is the conflict between state and federal laws. The federal government has been slow to introduce legislation that will help the legal marijuana industry. The legitimacy of the industry is put into question by the nature of storing cash in vaults, employing armored car services, and hiring security personnel (McKendry, 2016). The specific problem is that marijuana firms are forced to be cash-based businesses, which creates an increased risk of theft and difficulty in managing money. Thus, the emerging legal marijuana industry is hampered by the lack of banking services, which hurts the industry's legitimacy and creates increased security risks for its operators.

\section{Purpose of the Study}

The purpose of this hermeneutic phenomenology study was to explore the lived experiences of legal marijuana business owners in dealing with an increased risk of theft because they have no access to banking services. We collected information from current legal marijuana business owners to determine how the increased risk of theft and the difficulty of proper money management has affected their business (Shu-aquaye, 2016), which provided insight into how the industry can move to legitimacy with the current federal banking requisitions and help future business owners. 


\section{Significance to Social Change}

The outcome of this study may effect social change by helping inform current and future business owners about the risks of navigating in an industry without access to banking services. The exposure of the banking problem in this detailed study can help inform federal lawmakers of the adverse legal disadvantages that marijuana firms face. We examined the different reasons why legal marijuana firms were treated as illegal agents in a legal industry. The information, which is from dispensary owners and operators, has the elements that can push for positive social change in the legal marijuana industry.

\section{Conceptual Framework}

The conceptual framework was developed through the lens of Maslow's (1943) interpretation of how humans are motivated to maintain a safe environment to which they are accustomed. The concept map in Figure 1 illustrates the key concepts of this study and their relationship. The arrows in the concept map represent the complexity and interconnections between the many factors created by having no banking services available to the industry. This has caused legal marijuana businesses in Colorado to be cash-only operations, which has resulted in an unsafe environment of vaults and armored car services. Maslow explained that safety is an effective motivator when people are dissatisfied with their current safety procedures. But the landscape of the legal marijuana industry in Colorado presents challenges-no merchant services, no credit cards, and no debit cards. Cash-only operations involve security personnel, armored trucks, and hidden vaults. Legal marijuana business owners in Colorado have not had this standard version of safety that Maslow described. Many dispensary owners are not able to obtain and maintain bank accounts, which may make them targets for burglary and robbery (Pagliery, 2013).

The need for safety when not having a bank account was a strong motivation to seek acceptable solutions for safety and security. The businesses face a unique problem in terms of safety, security, and asset allocation due to handling large amounts of cash.

\section{Grounding Theories}

\section{Maslow's hierarchy of needs}

Abraham Maslow (1943) created the idea of personal motivation as it relates to needs. His hierarchy focused on the order in which individuals satisfy basic needs and move on to the next need. The conceptual framework of this study was based on the need of safety as a motivating factor for owners of legalized marijuana businesses in Colorado to create solutions to their cash-only banking status. Safety and financial well-being are in close relationship with the legal marijuana industry. Employees of marijuana firms in Colorado are involved with large amounts of cash and know that they are in a risky business. The emotional impact of their feeling of safety or lack of safety is a significant factor when faced with no banking services. Safety may also be expensive when factoring in security. 


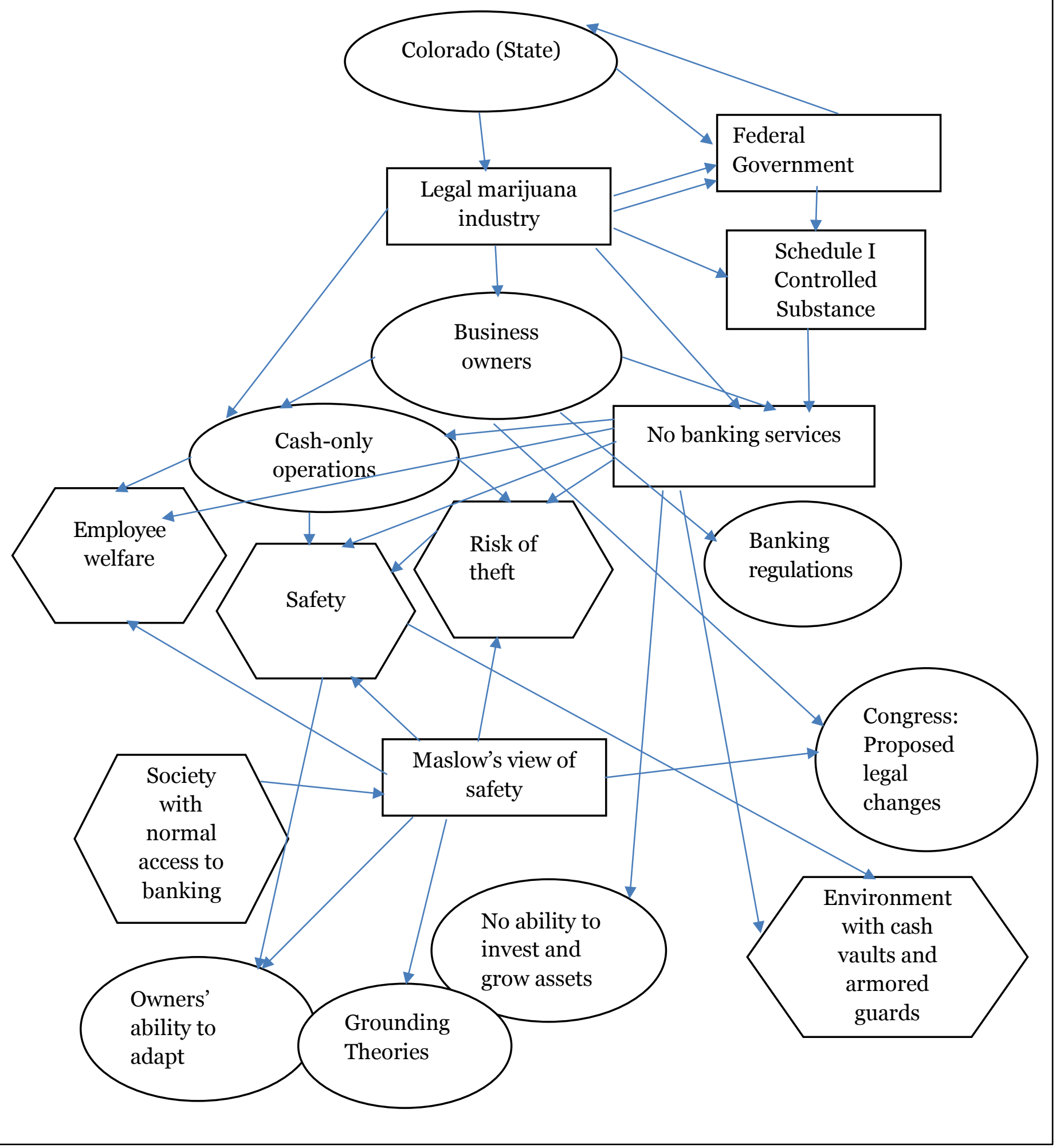

Figure 1. Concept Map of Colorado’s Legal Marijuana Industry From the Study's Perspective 


\section{Maslow and motivation}

Maslow (1943) discussed motivation and how it related to his hierarchy of needs, as needs motivate people. He classified these needs into two groups: deficiency needs and growth needs. The application of Maslow's theories to understand the motivations of business owners in the legal marijuana industry was essential to the study. The obstacle of no banking services creates several deficiency needs, such as safety needs and belonging needs. Maslow proposed that when a person lacks needs like safety, the motivation to get those needs is strong. Not having banking services or a normal level of safety activates the motivation to find a solution to this problem.

\section{Research Design}

The research design in this study involved a hermeneutic phenomenological approach. This approach was focused on the experiences of entrepreneurs in the legalized marijuana business of Colorado to answer the research question: What are the lived experiences of legal marijuana business owners in Colorado who do not have access to banking services to operate their businesses and conduct standard business transactions?

The units of analysis in qualitative research are experiences, not individuals or groups; the interest is about the experience itself and not about how it fits in the population (Polkinghorne, 2005). The central concept of this study was that entrepreneurs in the legalized marijuana industry of Colorado experienced higher risks than their counterparts in other industries because they did not have access to banking services. The lived experiences of business owners created valuable information that could effect social change and help shape future policies. In-depth interviews of the participants provided important themes. These themes were analyzed and summarized to help explain the participants' lived experiences and to understand the phenomena.

\section{Population and Sampling}

The study population was business owners and operators, such as managers, in the legal marijuana industry of Colorado without access to banking services or access to limited banking services during their operating history. The sampling strategy was to select business owners and operators in the Colorado market at random who met the criteria of operating a legal cash-based operation in the sale of legal marijuana. The data were collected via telephone interviews from eight business owners and/or operators in Colorado's legal marijuana industry.

\section{Research Setting}

All interviews were done by telephone at a designated time when the participants had privacy and could speak freely. We contacted legal marijuana companies throughout the state and in all different regions of Colorado. Colorado was the first state to legalize recreational marijuana in the United States. The COVID-19 pandemic caused unique restrictions and obstacles to the research setting that were different from any research collected in a different period. Data collection was more difficult because business owners were operating in an environment that imposed new limits in terms of available time to contribute to this study. Potential participants also cited the COVID-19 pandemic as an obstacle to adhere to the different restrictions and protocols for their dispensaries. 


\section{Data Analysis}

Interviews were recorded and transcribed and then coded for the major themes from each participant. The first level of coding involved distinct concepts and themes in the data. The concepts and themes were noted by the frequency of use in the description of the lived experiences and their significance to answering the research questions. The overarching concepts from the interviews were noted for their frequency in the transcripts. These were the first-level concepts and represented the major themes to be analyzed.

The next step was to analyze the data again and find subtle ideas that did not occur as often as the major themes; this was the second level of coding and represented the supporting codes. After we compiled the major themes and supporting codes (see Table 1), we reviewed the data to see if any unique ideas or practices stood out as possible follow-up questions to reinforce the member-checking process. The themes were reflected on and written into the text, which was interpreted for deeper meaning and reflections.

Table 1. Themes and Supporting Codes

\begin{tabular}{|c|c|c|c|c|}
\hline \multicolumn{5}{|c|}{ Themes } \\
\hline Cash & Safety & Banking & Business Size & METRC $^{*}$ \\
\hline \multicolumn{5}{|c|}{ Supporting Codes } \\
\hline Counting & Location & High fees & $\begin{array}{l}\text { Number of } \\
\text { employees }\end{array}$ & $\begin{array}{l}\text { Product } \\
\text { inventory }\end{array}$ \\
\hline Paying & Robbery & Hard to find & $\begin{array}{l}\text { Banking fees } \\
\text { affect profits }\end{array}$ & $\begin{array}{l}\text { Not a good cash } \\
\text { system }\end{array}$ \\
\hline Accounting & Armed guards & Extra steps & & \\
\hline Envelopes & Security & $\begin{array}{l}\text { Private broker } \\
\text { accounts }\end{array}$ & & \\
\hline $\begin{array}{l}\text { Multiple } \\
\text { countings }\end{array}$ & & Compliance & & \\
\hline
\end{tabular}

*Marijuana Enforcement Tracking Reporting Compliance

The researchers' ability to describe and interpret their experience is an integral part of the research process in a hermeneutic phenomenological study (Guba \& Lincoln, 1989). The hermeneutic cycle takes the first- and second-level coding and allows for reflective writing to further the analysis in the interpretative phrase. The interpretation phase of the hermeneutic cycle is the step that separates it from other qualitative data analysis processes.

\section{Themes}

The major themes that emerged from the data analysis were cash, banking, safety, and business size. Cash was a common theme due to the nature of the study and the nature of the business operations. Banking was also a primary issue because a central theme was whether the participant had a bank account. Safety was a concern on some level for every participant. The business size was also a common theme in the interviews because different dispensaries operated differently based on their size and location.

The major themes or first-level codes each had a group of supporting or second-level codes that could be 
grouped into categories. Each of the second-level codes helped describe the meaning and significance of the prominent themes from the interviews. The theme of cash was described by the second-level codes of counting, multiple counting, paying, accounting, and envelopes. These supporting codes captured activities of managing the cash. Participants described using envelopes to keep up with each day's transactions. They emphasized how, in a cash-only operation, counting the money multiple times was a check-and-balance process to ensure that the accounting was accurate and that there was nothing missing. Participants also discussed the heavy use of the ATM in their business (see Table 2).

Table 2. Theme 1: Cash

\begin{tabular}{|c|c|}
\hline Theme 1 & Textual Description (Comments From Participants) \\
\hline $\begin{array}{l}\text { Cash was the common mode of } \\
\text { payment for any goods and } \\
\text { services for customers, } \\
\text { owners, and vendors }\end{array}$ & $\begin{array}{l}\text { - Basically, this means having a lot of cash around all the time. } \\
\text { Sales to customers are only in cash. We also make all our } \\
\text { purchases from vendors with cash. We have our own system } \\
\text { that we have developed over the years. It typically involves } \\
\text { envelopes; we have the deposits from the previous day } \\
\text { prepared to be sent back to the owner once per week (P2). } \\
\text { Because we are a smaller business, we don't necessarily } \\
\text { need to count multiple times a day. We are not as pressed or } \\
\text { as busy as some of the bigger dispensaries or the ones in the } \\
\text { city. It is pretty much like a daily accounting (P3). } \\
\text { Yes, at my current position, we double count, we have my } \\
\text { closing manager in the evening close out and check all the } \\
\text { cash of course but my opening manager does that as well } \\
\text { (P6). }\end{array}$ \\
\hline
\end{tabular}

The textual descriptions from Theme 1 showed how cash dominated the day-to-day operations of the legal marijuana dispensaries interviewed. The businesses had different ways of managing how they accounted for and reconciled the cash they received. Each business had a procedure that worked for them, but the objective was the same. The businesses were trying to make sure they had accounted for all the cash.

The first-level code of banking was explained with the supporting codes of high fees, hard to find, extra steps, broker accounts, and employee accounts. The banking problem described by many participants affected the employees as well as the business as a whole. Seven of eight participants also spoke about the high fees when trying to obtain an account and having their business account canceled by the bank. Banks are documented as working with marijuana businesses, so when their lawyers advise them of the potential risks, banks cancel their accounts with those marijuana businesses. Even companies that obtained accounts were not treated like typical businesses. Fees were more than $\$ 1,000$ a month, and in some cases, they were $\$ 2,000$ per month (see Table 3). 
Table 3. Theme 2: Banking

\begin{tabular}{lc}
\hline Theme 2 & Textual Description (Comments From Participants) \\
\hline $\begin{array}{l}\text { Banking was described } \\
\text { by participants as hard } \\
\text { to find and maintain for } \\
\text { businesses and } \\
\text { employees }\end{array}$ & $\begin{array}{l}\text { The biggest fear I have is the worry that my employees' bank } \\
\text { accounts will get closed, and that usually only happens when } \\
\text { people need their bank account the most. So whether they are } \\
\text { vying for an auto loan or taking out a line of credit, and the bank } \\
\text { asks you where you work and you have to divulge that. Employees } \\
\text { have had their bank accounts just canceled. Alternatively, here in } \\
\text { Colorado, all employees are required to wear an identifier badge } \\
\text { showing that they work in the industry. Employees walk into a } \\
\text { bank, forgetting to take off their badge, and the bank manager has } \\
\text { closed their account during that visit (P6). } \\
\text { Before some banks began working with marijuana dispensaries, } \\
\text { there was no banking whatsoever, and most banks will still reject } \\
\text { you. This even goes further than just a business standpoint. It } \\
\text { affects our employees as well. I know of several cases, including } \\
\text { myself, where banks will turn away personal accounts or they will } \\
\text { deny you access to an account with them. I have seen them } \\
\text { terminate your account if they find out that your money is coming } \\
\text { from a dispensary; it's been very challenging (P4). } \\
\text { Yeah, I think, for me, one issue that I run into with banking is the } \\
\text { fees that they charge. You know they charge outrageous fees per } \\
\text { month for a small mom-and-pop business like myself. I cannot } \\
\text { afford those fees; it would eat up all my profits (P3). }\end{array}$ \\
\end{tabular}

The theme of safety produced supporting codes of location, robbery, armed guards, and security. All the participants were concerned about their safety because they were a cash-based business, even if they had limited access to banking (see Table 4). The participants cited location as a potential factor in the safety of the operation and the need for armed guards. Armed guards were seen as a useful deterrent to robberies in dispensaries where there were used. Participants felt that rural areas were safer than the Denver metro area in terms of the frequency of robbery and the need for security guards. 
Table 4. Theme 3: Safety

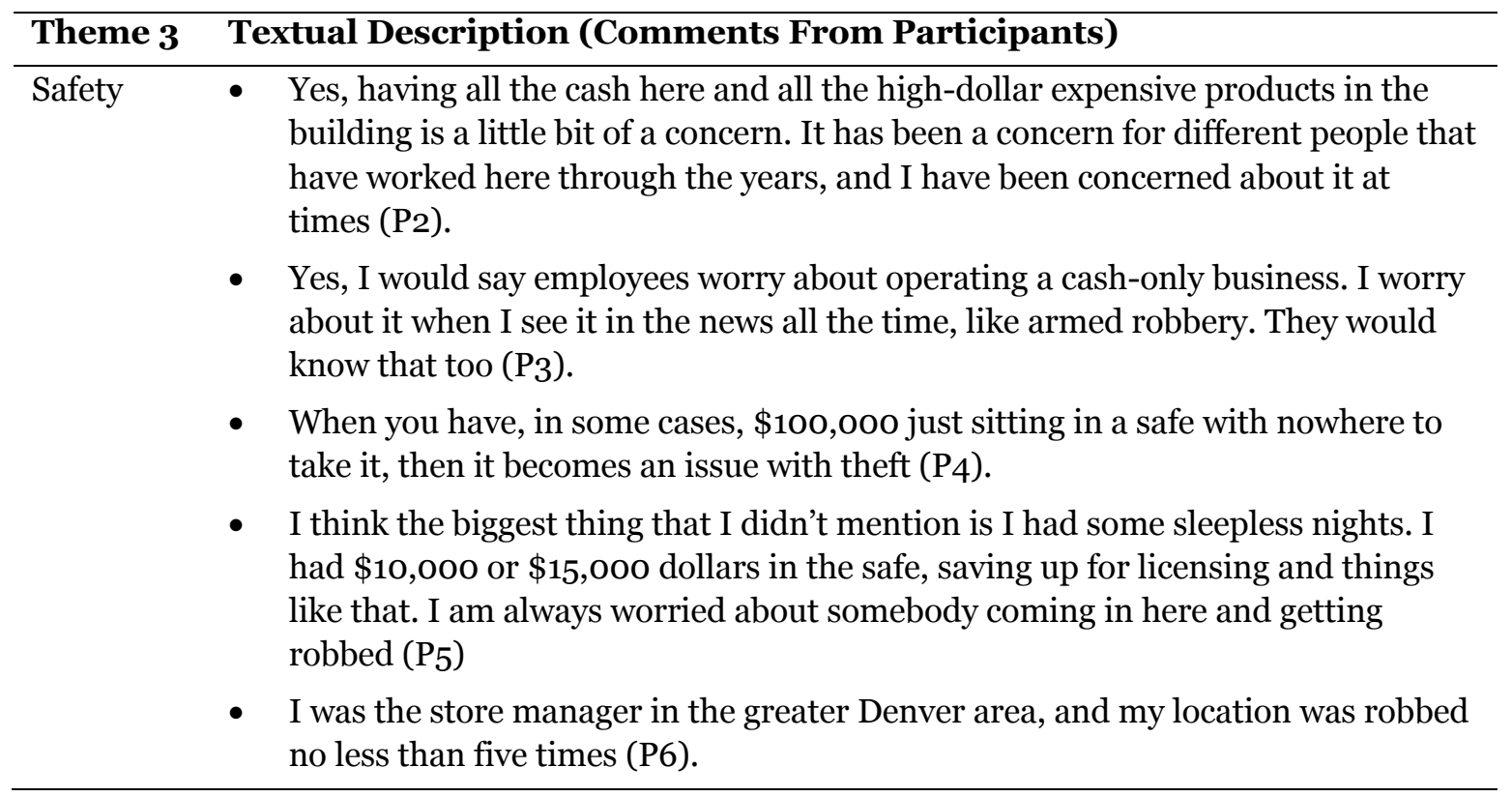

Safety was a primary focus in the literature review, and the participants explained how it was an ongoing concern in their businesses for many reasons. Marijuana dispensaries were common targets of robbery because of the amounts of cash they were forced to keep on hand because of their banking situation. The data collection provided textual descriptions of the role that safety played in the minds of the participants. All participants discussed the lucrative nature of their business and how the public had the perception that large amounts of cash were collected and kept on the premises.

The business size was a common theme in terms of cash handling and how the owners viewed their operation. Participants felt that smaller dispensaries were at a disadvantage in terms of paying high bank fees for accounts. They also felt that there were fewer hands involved in managing the handling of cash inside the business, which was an advantage in tracking any mistakes. The business's location and size were also factors in terms of security needs and the way the operators viewed security. Participant 2 summed up the overall sentiment of the small-town dispensary: "We are also in the middle of nowhere, and it is a small town, and we're not really concerned about that [being robbed] here specifically. I know that city shops have much more of a challenge with that."

\section{Interpretation of Findings}

The banking problem was found to be not only a business issue but also an employee issue. Employees in the industry are potential targets to have their accounts closed if banks discover they work in the industry. Bank accounts for legal marijuana businesses are also hard to find and expensive to maintain. Some participants chose to remain without a bank account after a few failed accounts at banking. All participants complained of the high banking fees, whether they held an account or not. The frustration with banking did not end once a dispensary found a bank; they were still unable to have merchant services and accept debit and credit cards, so they had to operate as a cash-only business and house large amounts of cash from operations. Businesses have incorporated the technology of cashless ATMs to mitigate the issue of not being able to accept debit cards. Further, cannabis businesses that maintained a bank account were still frustrated by the extra steps in the banking process. One participant was fortunate to have a bank account in the town where they worked, but many other dispensary owners have to drive hundreds of miles to get to their bank. The inability to write off business expenses, as 
noncannabis businesses do, can be another frustration. Some other dispensaries have used an accessory company, such as a pen or pipe company, in conjunction with their marijuana business to get some of the benefits of regular businesses, which could create an issue with taxing and accounting.

The marijuana business size was another major consideration for some businesses because the high banking fees did not allow the business to be profitable. Some participants chose to remain without a bank account to allow them to be profitable. The bank accounts were also unreliable because they had a history of suddenly being closed if the bank felt that there would be penalties from the federal government. Some business owners would like to see the fees scaled down for smaller operations to allow them an opportunity to have a bank account and maintain profitability. There is a distinct disadvantage to marijuana businesses because of high banking fees and the inability to write off expenses. These factors, accompanied by high tax rates, compromise the profitability of the legal marijuana industry in Colorado.

\section{Recommendations}

The primary recommendation to the federal government is to remove marijuana as a Schedule I Controlled Substance. This would help separate cannabis from other drugs and allow for changes in legislation. The federal government has been slow to adopt policies to help the legal marijuana industry even after a decade of legalization. Our research study's scope was to learn from actual owners and operators in the legal marijuana industry of Colorado. The eight participants in this study painted a vivid picture of their present-day situation. The recommendations for future research are in the area of technological processes that could aid the industry. The idea of a cashless ATM was introduced by $25 \%$ of the participants.

The cashless ATM is a way for the dispensaries to collect less cash. In such a process, they continue selling marijuana and paying for the product, but they are not generating more cash in the business. It is an ATM transaction that is used exclusively to purchase marijuana products. Future research could explore the tax and legal liabilities of having such a transaction. Future research could look at the advantages and disadvantages of this process. There is currently not much literature to explain the process in detail.

Participants described the process of the cashless ATM as a "workaround.” The retail teller machines (RTMs) are among the more commonly pitched compromises for high-risk merchants who cannot accept debit and credit cards because banks will not partner with them (Wynn, 2017). RTMs do not dispense cash, but instead, print a unique voucher, which is then exchanged for cash inside the same store. The retailer is immediately compensated by the RTM, which executes a bank-to-bank transaction. Cashless RTMs remit the dispensed amount into the retailer's bank account (KAL, 2012). Participants describe the process as a step toward more legitimate banking processes, but it is not a solution.

Another area of future research is that of tax deductions for legal marijuana companies. The industry is affected by marijuana being listed as a Schedule I drug under the Controlled Substances Act. The ability to take deductions like a normal business along with the adverse banking conditions affect the profitability of legal marijuana companies. Future research could measure the potential impact of tax laws against marijuana dispensaries. Several areas of the economic model of a business are significantly different for cannabis companies versus noncannabis companies. Future research could explore solutions for positive social change for the legal marijuana industry.

The concerns and frustrations of the participants of this hermeneutic phenomenological study pointed toward areas of future research: technology (cashless ATM), taxation, and legislation. Many different factors can help the legal marijuana industry become more legitimate and profitable. The obstacles to this industry are numerous, based on the current laws and business landscape. Future research can help people outside of the industry understand how each area will impact positive social change for the owners and operators of this industry. 


\section{Conclusion}

Cities and states have seen the benefits of tax revenue from the legal marijuana industry. For example, in 2015, Auroro, Colorado, disclosed how it was going to use its tax revenue. Aurora used $\$ 1.5$ million of its revenue from pot sales and fees to address its homeless issue. There are 62 cities and 22 counties in Colorado that allowed retail marijuana sales, according to the state, in 2015. Marijuana sales that year reached $\$ 1$ billion. The Colorado Department of Revenue reported consumers purchased slightly more than $\$ 2$ billion in cannabis products in Colorado from January through November 2020 (Ricciardi, 2021). The industry has experienced growth without the help of the federal government, but it has been difficult. The burden on the owners and operators of the industry is unfair, especially in the light of the COVID pandemic, which saw marijuana businesses deemed essential at the height of government lockdowns across the United States. The federal government has the power to remove the banking and tax burden from this emerging industry and reap the tax benefits as many states are currently doing. The potential of legalizing marijuana on the federal level, like Canada has done, could become a possibility in the future. Federal legalization would open the door for massive reforms in the areas of banking and taxation that would accelerate the growth of the marijuana industry. 


\section{References}

Eastman, J. (2016). Review of the book Weed land: Inside America's marijuana epicenter and how pot went legit by P. Hecht (Ed.). Contemporary Sociology, 45(1), 50-51.

http://www.jstor.org/stable/43997402

Guba, E. G., \& Lincoln, Y. S. (1989). Fourth generation evaluation. Sage.

KAL. (2012, June 19). Cashless ATM to change face of branchless banking. KAL News and Events. https://www.kal.com/en/kal-atm-news/cashless-atm-to-change-face-of-branchless-banking-2

Kamin, S., \& Moffat, V. R. (2016). Trademark laundering, useless patents, and other IP challenges for the marijuana industry. Washington and Lee Law Review, 73(1), 217-283. https://scholarlycommons.law.wlu.edu/wlulr/vol73/iss1/6

Maslow, A. H. (1943). A theory of human motivation. Psychological Review, 5O(4), 370.

McKendry, I. (2016). Senators push regulators for clearer guidance on banking businesses. American Banker, 181(58), 1. https://www.americanbanker.com/news/senators-push-regulators-for-clearerguidance-on-banking-pot-businesses

Pagliery, J. (2013, April 30). Legal marijuana's need for high security. CNN Money. http://money.cnn.com/2013/04/29/smallbusiness/marijuana-security/

Polkinghorne, D. E. (2005). Language and meaning: Data collection in qualitative research. Journal of Counseling Psychology, 52(2), 137-145. https://doi.org/10.1037/0022-0167.52.2.137

Ricciardi, T. (2021, January 13). November marijuana sales push Colorado's industry to $\$ 2$ billion annually for the first time: Those monthly sales cooled off, they were enough to hit another financial milestone. The Denver Post. https://www.denverpost.com/2021/o1/13/november-marijuana-sales/

Shu-aquaye, F. (2016). The unintended consequence to legalizing marijuana use: The banking conundrum. Cleveland State Law Review, 64(2), 315-328.

https://engagedscholarship.csuohio.edu/clevstlrev/vol64/iss2/10.

Wynn, S. (2017). Cashless ATMs: An imperfect solution to legal pot's bank problem. American Banker, 182(155), 1.

The Journal of Social Change, sponsored by Walden University, welcomes manuscripts focusing on interdisciplinary research in social change that improves the human condition and moves people, groups, organizations, cultures, and society toward a more positive future. 